\title{
Consentimiento Informado
}

\author{
Informed consent \\ Rodrigo López-Falcony* \\ * Secretario Técnico del Centro Estatal de Trasplantes del Estado de Guanajuato.
}

El consentimiento informado, además de ser un requisito legal para todo acto médico normado por la Ley General de Salud, tiene la función de informar explícitamente todas las implicaciones del acto médico a realizar. Asimismo, implica la obligación del médico de establecer un proceso de comunicación con su paciente para que ambos tengan la información comprensible y necesaria para tomar decisiones que permitan enfrentar de mejor manera la enfermedad. De esta forma percibimos que el consentimiento informado es mucho más que solicitar una firma, es un proceso de comunicación en el cual el médico y el paciente se deben poner de acuerdo y entender que la finalidad es atender el padecimiento del enfermo por el bien del mismo.

Aunque también lo podemos considerar como un derecho del paciente que constituye a la vez una exigencia jurídica para el médico, que tiene además un fundamento ético y una finalidad clínica; de ahí que no sólo sea una exigencia legal, sino que es, primordialmente, una actividad que tenemos que realizar los médicos frente a nuestros pacientes.

En el tema de trasplante, el consentimiento informado adquiere una importancia superlativa en el donador, ya que es una persona sana que se someterá a un procedimiento quirúrgico con el único fin de beneficiar a alguien más. Por esta peculiar situación sus expectativas son diferentes a las del resto de los pacientes.

La carta del consentimiento bajo información, de acuerdo con la Norma Oficial Mexicana del Expediente Clínico NOM-004-SSA3-2012, se define como el documento escrito, signado por el paciente o su representante legal, mediante el cual se acepta, bajo debida información de los riesgos y beneficios esperados, un procedimiento médico o quirúrgico con fines diagnósticos, terapéuticos o rehabilitatorios; es revocable mientras no se inicie el procedimiento y no obligará al médico a realizar u omitir un procedimiento cuando ello entrañe un riesgo injustificado hacia el paciente. Si durante la intervención tenemos que realizar algún procedimiento para el cual no se había solicitado el consentimiento, y si es para beneficio del paciente, el médico está obligado y autorizado a hacerlo. En esta norma se explica el consentimiento informado según su índice en el apartado 10.1 y se muestran los puntos que deberá contener como mínimo, esto en el inciso 10.1.1 (con subincisos 10.1.1.1 a 10.1.1.9).

En el título décimo cuarto de la Ley General de Salud se estipulan los elementos y disposiciones legales que deben contemplarse en donación/trasplante y en la elaboración del consentimiento informado, los artículos que habrá que observar son los comprendidos del 322 al 333 y los artículos del Reglamento de la Ley General de Salud que se ocupan de la materia y que también deberán cumplirse son el 9 y el 17.

Organismos internacionales sugieren que además de las disposiciones oficiales y la descripción minuciosa del procedimiento y sus complicaciones a corto, mediano y largo plazo se deba incluir lo siguiente:

En el donador incluir:

- Evaluación para determinar la habilidad del donador para entender el proceso donación-trasplante, incluida sus complicaciones y riesgos.

- Otorgar materiales impresos explicando cada parte del proceso de donación en vida. 
- Especificar los cuidados postquirúrgicos inmediatos, mediatos y a largo plazo.

- Comunicar las opciones que tendría el receptor de no llevarse a cabo la donación en vida.

- Asegurar la confidencialidad de la información médica del donador, en caso de presentar una condición de riesgo para el receptor, para lo cual no se llevaría a cabo el trasplante.

- Dejar por escrito los posibles riesgos quirúrgicos:

- Muerte, función renal postquirúrgica temporalmente comprometida, insuficiencia orgánica ameritando trasplante futuro, cicatrices, dolor.

En el receptor incluir:

- Evaluación para determinar la habilidad del receptor para entender el proceso donación-trasplante, incluida sus complicaciones y riesgos.

- Otorgar materiales impresos explicando cada parte del proceso de trasplante.

- Especificar los cuidados postquirúrgicos inmediatos, mediatos y a largo plazo.
- Comunicar las opciones que tendría el receptor de no llevarse a cabo el trasplante.

- Dejar por escrito los posibles riesgos quirúrgicos además de los habituales:

- Hemorragia masiva, lesión vascular, perforación víscera hueca, falla del injerto, falla orgánica múltiple, coagulopatía, cardiopatía isquémica, transmisión de agentes infecciosos procedentes del donador.

- Dejar por escrito los posibles riesgos psicosociales:

- Problemas de imagen, depresión, ansiedad.

- Posibilidad de rechazo del órgano, retrasplante, o muerte.

- Cambios en estilo de vida y entorno familiar.

- Potenciales riesgos financieros (durante convalecencia y posteriormente por historial médico).

- En mujeres especificar las consideraciones durante el embarazo.

Correspondencia:

Dr. Rodrigo López-Falcony

E-mail: Ifalcony@ @otmail.com 